\title{
Estimations of Pistia stratiotes L. by using Chromatographic Methods
}

\author{
Said Uttiya Ansar*, SV Manikantam and Kulkarni VB
}

Priyadakshin College of Technological Sciences, MH Koskote, Mandya, Karnataka, India

${ }^{*}$ Corresponding author: Said Uttiya Ansar, Assistant Professor, Priyadakshin College of Technological Sciences, MH Koskote, Mandya, Karnataka, India, Tel: 91-9739355742, 082-32220043; E-mail: uttiya_212@rediffmail.com

Rec date: April 21, 2014; Acc date: May 12, 2014; Pub date: May 20, 2014

Copyright: (C) 2014 Ansar SU, et al. This is an open-access article distributed under the terms of the Creative Commons Attribution License, which permits unrestricted use, distribution, and reproduction in any medium, provided the original author and source are credited.

\begin{abstract}
The leaf methanolic extract scavenged each gas $\mathrm{NO}$ and DPPH radical with a dose dependent manner. However the pet ether fraction of root was found to possess highest effectuality in $\mathrm{Fe}^{3+}$ reducing power assay. Flavonoid was found to contain highest within the pet ether fraction of root in terms of quercetin equivalent, equally highest quantity of total phenolic resin compounds (assayed as acid equivalents) were found to contain within the same fraction. The methanol fractions appeared less cytotoxic compared to pet ether extracts. The plant extracts caused a dose dependent decrease in soiled BM in each cathartic and atomic number 12 sulfate induced looseness of the bowels, wherever as leaf extracts in every solvent appeared only. Also, the plant extracts showed anthelmintic activity in oligochaete worm by causing palsy and death in an exceedingly dose dependent manner. At highest doses all fractions were nearly effective because the positive management helminthic citrate.
\end{abstract}

Conclusion: Thus, besides this cytotoxic effect its traditional claim for therapeutic use can never be overlooked.

Keywords: Pistia stratiotes L; Anthelmintic; Oligochaete worm; Sulfates

\section{Introduction}

P. stratiotes L. (Araceae) may be an unremarkably found aquatic plant organ herb in Asian country. As associate ayurvedic medication pistia L. (Araceae) has long been employed in this landmass, in numerous countries of continent and in China. variety of healthful property has attributed to the current plant, as well as antioxidant [1], investigation has dole out on the premise of its chemical constituents, however still thirty two several space of its therapeutic utility or untapped.

Many folkloric claims of effects of this pistia $\mathrm{L}$, insisted us to figure extensively and create rational, of its uses and establish its potentiality as a drug candidate. Within the course of this screening program, medical specialty properties of methanolic and pet ether extracts of each leaf and root were investigated in numerous scientifically established model. Experiments enclosed of this plant extracts were inhibitor activity particularly DPPH radical scavenging assay, $\mathrm{Fe}^{3+}$ particle reducing power [2], gas scavenging assay [3-5], total synthetic resin contents [6], total flavonoid contents [7], toxicity assay by branchiopod morbidness assay [8], antidirrhoeal activity [9], and anthelmintic activity [2] anthelmintic [2], and against Hansen/'s disease, eczema, piles, ulcers, and syphilis [3], plenty of pharmacological effects.

\section{Plant Collection and Identification}

The semi aquatic whole plant, $P$. stratiotes L., was collected in Gregorian calendar month 2010, from a pool placed in Jahangirnagar University, Savar, Dhaka, once correct identification has done by the National Herbarium, Asian country (accession range 35621).

\section{Extract Preparation}

The whole plant was completely washed into water, sun dried for daily then the leaves and roots are separated. Once the separation had been completed, the leaves and roots were unfolding in skinny layers in trays and at last placed into an appliance $\left(\right.$ at $\left.55^{\circ} \mathrm{C}\right)$ [10]. The coarse powder of the dried plant components of $P$. stratiotes L. were extracted one by one with the solvent pet ether and wood alcohol during a soxhlet equipment mistreatment $100 \mathrm{~g}$ powder for every half. Once the powders became exhausted of its chemical constituents as evident from cycles of colorless liquid siphoning within the soxhlet equipment, extraction was thought-about to be complete. Once completion of the extraction, the liquid was filtered by a sterile cotton plug. Then solvent was gaseous mistreatment water tub and therefore the final sediment was used for the experiments. Customary procedures were followed for the phytochemical screening [10].

\section{Assortment and Maintainance of Animals}

In order to research the antidiarrhoeal, sedative effects of this plant extracts, three to four weeks aged Swiss anomaly mice of each sex, of around twenty to twenty five $\mathrm{g}$ weight, were collected from the International Center for diarrhoetic malady and analysis, Asian nation (ICDDRB). Animals were caged in teams of five, in cages of $(28 \times 22 \times 13 \mathrm{~cm})$ dimension, with dry wadding as flooring. Temperature was maintained $25^{\circ} \mathrm{C}$ with fifty five to sixty fifth ratio and twelve hrs light/12 hrs dark for the complete study time. Food pellets were provided from ICDDR, B with $\mathrm{H}_{2} \mathrm{O}$ and libitum.

\section{Inhibitor Activity takes a look at by DPPH Radical Scavenging Assay}

Antioxidant activities by one, 1-diphenyl, 2-picrylhydrazyl (DPPH, alphabetic character USA) of plant elements were determined following the strategy of Oyaizu [4]. In brief, three milliliter 
methanolic resolution containing $0.004 \% \mathrm{DPPH}$ was further in an exceedingly in a very tube with an aliquot of a hundred $\mu \mathrm{L}$ of either extract or standard(ascorbic acid), and unbroken in dark for 30min for the reaction to require place, then absorbance taken at $517 \mathrm{~nm}$ against a blank (methanol). \% of activity make up my mind by - the concerns Scavenging $=\mathrm{X}$ a hundred $\mathrm{A} 1$ is that the absorbance of the samples/ standard and $\mathrm{A} 0$ is that the absorbance of the management.

\section{Inhibitor Activity take a look at by NO (nitric oxide) Scavenging Assay}

Scavenging of NO of the plant extracts were assayed in line with the Govindarajan [5] with slight changed methodology. Briefly, 1.0 milliliter of $5 \mathrm{mM}$ resolution of Na nitroprusside was mixed with four.0 milliliter of extract/ascorbic acid (standard) and unbroken in incubation at thirty 0C for two hours. Then 1.2 milliliter of Griess chemical agent (Roch-light Ltd., Suffolk, England) was mixed with two. 0 milliliter aliquot of that mixture and absorbance taken at 550 $\mathrm{nm}$. This was explained in Figure 1.

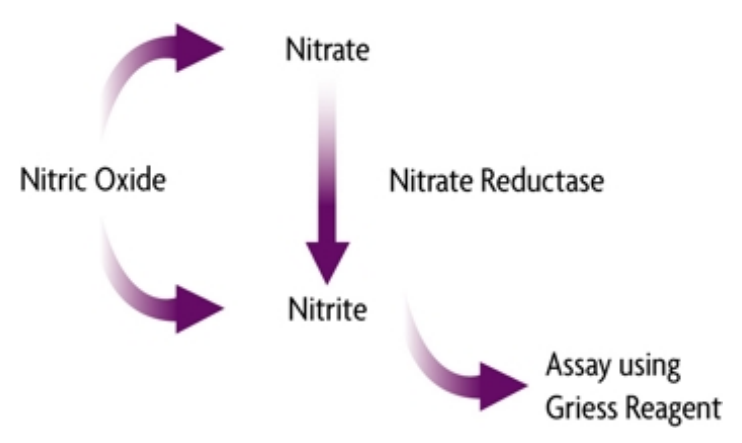

Figure 1: Nitrate Assay.

\section{Inhibitor Activity take a look at by $\mathrm{Fe}^{3+}$ Reducing Power}

The reducing capability may be termed as associate degree inhibitor activity of any compound. Reduction of metal Chloride $\left(\mathrm{FeCl}_{3}\right.$, Fine Chemicals, India) to $\mathrm{Fe}^{2+}$ determined by measure the colour at $700 \mathrm{~nm}$ [4]. Briefly, 2.0 milliliter every of extract or antioxidant (standard) of assorted concentration were taken in take a look at tubes. Then 2.5 milliliter of one hundred and twenty fifth $\mathrm{K}$ salt $\left[\mathrm{K}_{3} \mathrm{Fe}(\mathrm{CN})_{6}\right]$ and a couple of 0.5 milliliter trichloro carboxylic acid (10\%) were further, preceded by $10 \mathrm{~min}$ incubation at $50^{\circ} \mathrm{C}$. when centrifuging the mixture $10 \mathrm{~min}$ at 3000 rate, 2.5 milliliter aliquot was withdrawn and mixed with sterile water $(2.5 \mathrm{~mL})$ and $0.1 \%$ metal chloride eighty nine $(0.5$ $\mathrm{mL}$ ) resolution and at last the absorbance taken at $700 \mathrm{~nm}$.

\section{Phenoplast Content Determination}

Phenolic contents of the plant fractions were analyzed in line with $\mathrm{Yu}$ [6]. Dilute (10 fold) Folin-ciocalteu chemical agent $(5 \mathrm{ml})$ was further in tube containing 1.0 milliliter every of extracts $(200 \mu \mathrm{g} / \mathrm{mL})$ or customary (gallic acid, Sigma Chem. USA) and $4 \mathrm{~mL}$ washing soda resolution and was incubated for one hour at $20 \mathrm{oC}$ followed by absorbance taking at $765 \mathrm{~nm}$.

\section{Flavonoid Content Determination}

Flavonoid content of the plant fractions were calculable by Kumaran [7]. Where, 1.0 milliliter of extracts $(200 \mu \mathrm{g} / \mathrm{mL})$ or customary (quercetin, Sigma Chem.USA) was mixed with wood alcohol $(3 \mathrm{~mL}), 100 \%$ chloride $(200 \mu \mathrm{L}), 1.0 \mathrm{M} \mathrm{K}$ acetate $(200 \mu \mathrm{L})$ and water $(5.6 \mathrm{~mL})$. Absorbance was taken at $415 \mathrm{~nm}$ when $30 \mathrm{~min}$ keeping the mixture at temperature. Flavonoid contents of the fractions were calculated and shown as quercetin equivalents $(\mathrm{QE})$ by the subsequent formula:

$$
\mathrm{C}=(\mathrm{c} \times \mathrm{V}) / \mathrm{mC}
$$

total flavonoid contents in $\mathrm{mg}$ per weight unit plant extract, $\mathrm{c}$, concentration of quercetin calculated byuarcetin customary curve $(\mathrm{mg} / \mathrm{ml}), \mathrm{V}$, sample resolution volume $(\mathrm{mL}), \mathrm{m}$, sample weight $(\mathrm{g})$.

This was detailed in chromatographic spectrum of Pistia Stratois in below figure:

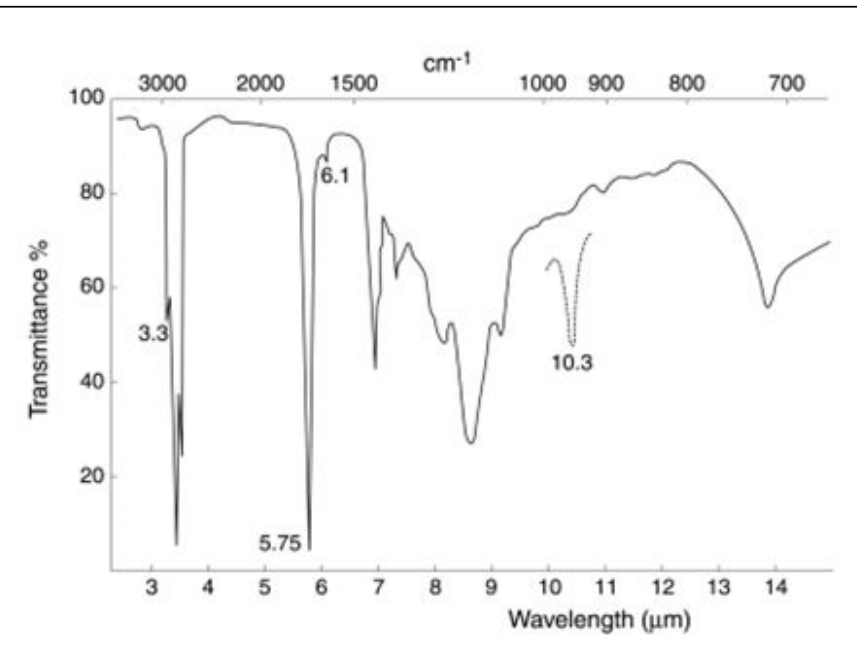

Figure 2: Brand spectrum of Pistia Stratois.

\section{Artemia Salina Deadliness Bioassay}

Cytotoxicity of the plant extracts were determined by Artemia salina deadliness bioassay delineated by Meyer) [8]. Nauplii were collected from Artemia salina eggs when hatching in simulated water $(38 \mathrm{~g} / \mathrm{L}) .10$ nauplii area unit taken in vials containing five milliliter of simulated water treated with extracts dissolved in DMSO. The median fatal concentration, LC50 values of the take a look at samples were calculated when twenty four hours, and obtained by a plot of proportion of dead Shrimps verses the sample concentration (in Log scale) victimization Microsoft surpass. Periwinkle plant derivative sulfate was utilized, as a reference cytotoxic molecule [8].

\section{Antidiarrhea Activity take a look at Induced by Physic / Atomic Number Sulfate}

Shoba and Thomas [9] have incontestable the strategy. Briefly, 10 teams of mice having five animals in everywhere fasted for twenty-four $\mathrm{h}$ then fed 0.5 milliliter of physic, and people animal with watery stool were selected for the ultimate experiment. Treated cluster mice received four completely different fractions of pistia at the doses of two hundred $\mathrm{mg} / \mathrm{kg}$ and four hundred $\mathrm{mg} / \mathrm{kg}$, whereas loperamide $(3 \mathrm{mg} /$ 
$\mathrm{kg}$ ) was as positive and solely vehicle as negative management and every one were administered orally. the complete teams of animal were fed 0.5 milliliter every of physic orally to provide looseness of the bowels when $1 \mathrm{~h}$ and placed in a personal cage 119 lined by paper that was replaced with new one on each hour for a $4 \mathrm{~h}$ observation of diarrhoetic dropping. On the opposite hand, in atomic number 12 sulfate $(2 \mathrm{~g} / \mathrm{kg})$ was orally administered thirty min later from the drug/ control treatment to provide looseness of the bowels.

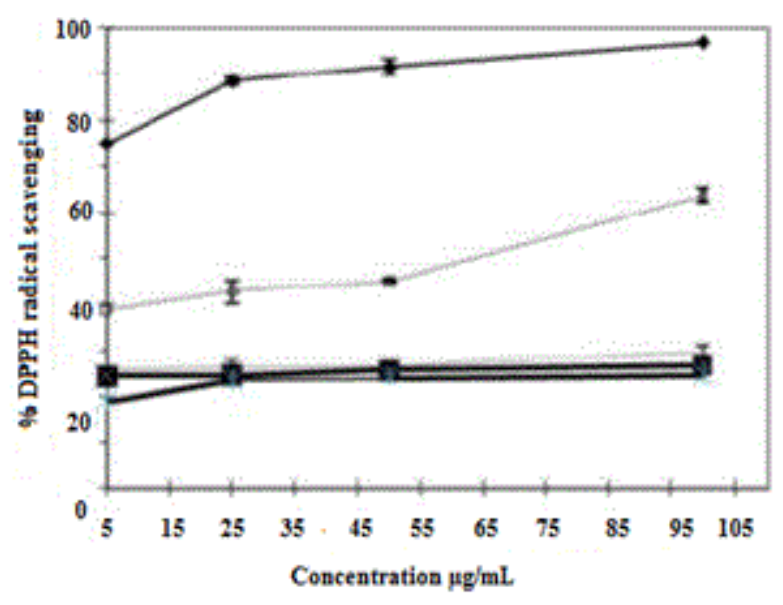

Figure 3: Inhibitor activity of various fractions of $P$. stratiotes.

\section{Anthelmintic Activity}

Anthelmintic potential of the plant fractions make up my mind in line with the given methodology of Ajaiyeoba [2]. Pheretima posthuma, associate degree anatomically similar species of roundworm was taken for this assay. Earthworms of spherical four to eight $\mathrm{cm}$ long and 0.2 to $0.4 \mathrm{~cm}$ broad were placed 3-in every dish containing $25 \mathrm{~mL}$ every often, twenty five and fifty $\mathrm{mg} / \mathrm{mL}$ extract in water containing one hundred and twenty fifth tween eighty. anthelminthic turn (10 and twenty $\mathrm{mg} / \mathrm{mL}$ ) and one hundred and twenty fifth tween eighty in water, used as positive and negative management, severally. Time for causation disfunction was measured by visual observation with occasional shaking, finally death was confirmed by losing the whole movement with vigorous shaking and exposing to heat water of five hundred $\mathrm{C}$ temperature and pale look.

\section{Discussions}

In the gift phytochemical and pharmacologic screening of various fractions of root and leaf of $P$. stratiotes $\mathrm{L}$ discovered the presence of assorted bioactive elements like flavonoids, alkaloids, glucosides and steroids (Table 1), that square measure correlative with some observations of others. The take a look at for inhibitor by DPPH radical scavenging capability of neither fractions of this plant extracts were shown pretty much as good effectivity as in gas (NO) scavenging assay, but methanolic leaf extracts had very little improved activity (Figure 1). In gas (NO) radical scavenging assay, each methanolic and pet ether fractions of leaf extracts were shown to possess the NO scavenging ability near the reference customary, antioxidant, in an exceedingly dose dependent manner. This invivo scavenging of NO, generated from atomic number 11 nitroprusside to additional forestall peroxynitrite particle formation is anticipated to require place within the cell in vivo [11]. Therefore, NO scavenging activity of P. stratiotes L. fractions may impart a cytoprotective impact.

\begin{tabular}{|l|l|l|l|l|}
\hline Contents & PSLM & PSLP & PSRM & PSRP \\
\hline Alkaloid & + & + & + & + \\
\hline Glycoside & + & - & - & - \\
\hline Glucoside & + & + & + & + \\
\hline Carbohydrate & + & - & + & - \\
\hline Tannin & - & + & + & + \\
\hline Flavonoid & + & + & + & + \\
\hline Steroid & + & + & - & + \\
\hline Saponin & + & - & - & - \\
\hline
\end{tabular}

Table 1: Extracts containing different chemical constituents. (+, Present, -, Absent, PSLM, Methanolic fraction of leaf, PSLP, Pet ether fraction of leaf, PSRM, Methanolic fraction of root, and PSRP, Pet ether fraction of the root in P. stratiotes L.)

The reducing power displayed by all the fractions of $P$. stratiotes $\mathrm{L}$. was found to rise with increasing concentrations (Figure 1). Since it absolutely was antecedently mentioned the role of reductants [12], in reducing ability by donating atom to interrupt the radical chain [13]. Therefore, it absolutely was speculated that the presence of reductants (i.e. antioxidants) in P. stratiotes L. fractions could elicit the reduction of the $\mathrm{Fe}^{3+} /$ ferricyanide complicated to the metallic element kind.

Several reports have concerned the role of flavonoids and phenolic resin compounds in NO scavenging [14-16] and therefore the relationship between antioxidative activity and total phenolic resin contents [17]. The total flavonoid and phenolic resin contents determination discovered the very best quantity gift within the pet ether root extract, $34.96 \mathrm{mg} / \mathrm{g}$ and $411.35 \mathrm{mg} / \mathrm{g}$ phenolic resin and flavonoid content severally. however during this study, we tend to found to possess the NO scavenging and antioxidative activity was higher correlative with methanolic leaf extracts, that contains less flavonoid $(153.93 \mathrm{mg} / \mathrm{g})$ and phenolic resin compounds $(21.23 \mathrm{mg} / \mathrm{g})$ than the foundation extracts, different constituents may synergistically elicit the impact here [18].

The plant extract was found to possess dose dependent antidiarrheal drug activity within the take a look at animals. Leaf extracts of each wood spirit and pet ether square measure shown to be most efficacious (P\&lt, 0.05) than different components in each physic and $\mathrm{MgSO}_{4}$ induced diarrhetic model (Tables 2 and 3). But root extracts additionally possess some anti diarrhetic effects too, that seems in its higher dose $(400 \mathrm{mg} / \mathrm{kg})$ in those ways. antecedently it absolutely was reportable that antidiarrhoeal properties of healthful plants may attributed with alkaloids, tannins, saponins, flavonoids, sterols and reducing sugars [19] and flavonoids, could contribute to inhibit unharness of autacoids and prostaglandins (ricinoleic acid of physic induce irritation and inflammation of enteric mucosa) [20], and stop motility.

Values square measure mean \pm SEM, $(n=5),{ }^{\star} P$ \&lt, 0.05, Dunnet take a look at as 183 compared to manage. Vehicle, one hundred and twenty fifth Tween eighty in water, $0.4 \mathrm{~mL} /$ mouse, PSLM, Methanolic fraction of leaf, PSLP, Pet ether fraction of leaf, PSRM, Methanolic 
Page 4 of 5

fractions of the root, and PSRP, Pet ether fraction of the root in P. stratiotes $\mathrm{L}$.

\begin{tabular}{|c|c|c|c|c|}
\hline $\begin{array}{l}\text { Grou } \\
\text { p }\end{array}$ & Treatment & Dose & $\begin{array}{l}\text { No. of feces in } 4 \\
h\end{array}$ & $\begin{array}{l}\% \\
\text { defecation }\end{array}$ \\
\hline I & Vehicle & $\begin{array}{l}0.4 \\
\text { mUmouse }\end{array}$ & $22.8 \pm 3.148$ & - \\
\hline II & Loperamide & $3 \mathrm{mg} / \mathrm{kg}$ & $5.9 \pm 1.872$ & 73.82 \\
\hline III & \multirow{2}{*}{ PSLM } & $200 \mathrm{mg} / \mathrm{kg}$ & $14.4 \pm 1.346^{\prime}$ & 36.65 \\
\hline IV & & $400 \mathrm{mg} / \mathrm{kg}$ & $10.8 \pm 2.479^{\prime}$ & 52.41 \\
\hline V & \multirow{2}{*}{ PSLP } & $200 \mathrm{mg} / \mathrm{kg}$ & $13.3 \pm 2.346^{\prime}$ & 41.68 \\
\hline VI & & $400 \mathrm{mg} / \mathrm{kg}$ & $9.2 \pm 1.453^{\prime}$ & 59.54 \\
\hline VII & \multirow{2}{*}{ PSRM } & $200 \mathrm{mg} / \mathrm{kg}$ & $19.6 \pm 2.864$ & 13.83 \\
\hline VIII & & $400 \mathrm{mg} / \mathrm{kg}$ & $19.1 \pm 2.245$ & 16.23 \\
\hline IX & \multirow{2}{*}{ PSRP } & $200 \mathrm{mg} / \mathrm{kg}$ & $18.9 \pm 3.012$ & 16.92 \\
\hline$x$ & & $400 \mathrm{mg} / \mathrm{kg}$ & $14.88 \pm 2.429^{\prime}$ & 34.85 \\
\hline
\end{tabular}

Table 2: Effects of the different fractions on castor oil-induced diarrhea in mice.

\begin{tabular}{|c|c|c|c|c|}
\hline $\begin{array}{l}\text { Grou } \\
\text { p }\end{array}$ & Treatment & Dose & $\begin{array}{l}\text { No. of feces in } \\
4 \mathrm{~h}\end{array}$ & $\begin{array}{l}\% \quad \text { inhibition of } \\
\text { defecation }\end{array}$ \\
\hline 1 & Vehicle & $\begin{array}{l}\text { OA } \\
\text { mUmouse }\end{array}$ & 16.833 .597 & \\
\hline II & $\begin{array}{l}\text { Loperamid } \\
\mathrm{e}\end{array}$ & $3 \mathrm{mg} / \mathrm{kg}$ & 5.732 .019 & 65.89 \\
\hline III & \multirow{2}{*}{ PSLM } & $200 \mathrm{mg} / \mathrm{kg}$ & $11.322 .347^{\prime}$ & 32.98 \\
\hline IV & & $400 \mathrm{mg} / \mathrm{kg}$ & $9.031 .271^{\prime}$ & 46.57 \\
\hline V & \multirow{2}{*}{ PSLP } & $200 \mathrm{mg} / \mathrm{kg}$ & 10.833.175' & 35.98 \\
\hline VI & & $400 \mathrm{mg} / \mathrm{kg}$ & $8.2 \pm 1.067^{*}$ & 51.04 \\
\hline VII & \multirow{2}{*}{ PSRM } & $200 \mathrm{mg} / \mathrm{kg}$ & 14232.457 & 15.45 \\
\hline VIII & & $400 \mathrm{mg} / \mathrm{kg}$ & 13.831 .917 & 17.74 \\
\hline IX & \multirow{2}{*}{ PSRP } & $200 \mathrm{mg} / \mathrm{kg}$ & 14.632 .421 & 12.89 \\
\hline $\mathrm{x}$ & & $400 \mathrm{mg} / \mathrm{kg}$ & $11631245^{\prime}$ & 31.07 \\
\hline
\end{tabular}

Table 3: Effects of the various fractions of P. stratiotes on $\mathrm{MgSO}_{4}$ induced symptom in mice. Values square measure mean $\pm \mathrm{SEM},(\mathrm{n}=$ $5),{ }^{\star} \mathrm{P} \& \mathrm{lt}, 0.05$, Dunnet take a look at as compared to manage.

Vehicle, one hundred and twenty fifth Tween eighty in water, 0.4 $\mathrm{mL} /$ mouse, PSLM, Methanolic fraction of leaf, PSLP, Pet ether fraction of leaf, PSRM, Methanolic fraction of root, and PSRP, Pet ether fraction of the root in P. stratiotes L. to boot we tend to additionally found a dose dependent anthelmentic property of this plant extracts within the in vitro anthelmintic assay victimization adult earthworm (Table 4). Of its highest dose $(50 \mathrm{mg} / \mathrm{mL})$ oil root extract had taken virtually same time $(6.5 \mathrm{~min})$ like the positive management anthelminthic citrate $(10 \mathrm{mg} / \mathrm{mL})$ however it circle with the foundation methanolic extract (13.5 $\mathrm{min})$. Shows that the anthelmintic compound was largely extracted in pet ether fraction. Several polyphenolic compounds as well as niclosamide, oxyclozanide and bithionol square measure concerned with anthelmintic activity by uncoupling 196 biological process of parasites [21]. The anthelmintic activity of P. stratiotes L. could also be ascribed by the presence of flavonoids, tannins, steroids (Table 1) etc in P. stratiotes, and every one square measure gift within the root pet ether extract.

The pet ether fractions of each leaf and root extracts were shown to possess higher toxicity within the Artemia salina Assay [22], LC50 values square measure 121.99 and $45.80 \mu \mathrm{g} / \mathrm{mL}$ for leaf and root, severally. On the opposite hand the methanolic fractions appeared relatively less toxicant, LC50s square measure 424.58 and 6217.75 $\mu \mathrm{g} / \mathrm{mL}$ for leaf and root, severally. The study displayed the cytotoxic action increasing with the increment of doses indicating the plant could have some cytotoxic principles. many phytochemical constituents were known during this plant components (Table 1). Stigmastane, a brand new hormone cytotoxic part is reportable to gift during this plant structure [23].

\begin{tabular}{|c|c|c|c|}
\hline \multirow{2}{*}{ Treatment } & \multirow{2}{*}{ Concetration $(\mathrm{mg} / \mathrm{mL})$} & \multicolumn{2}{|c|}{ Time taken for Time taken for } \\
\hline & & paralysis(min) & death $(\min )$ \\
\hline \multicolumn{4}{|c|}{ Vehicle ( $1 \%$ Tween 80 in Water) } \\
\hline \multirow{3}{*}{ PSLM } & 10 & 41.511 .243 & 59.010 .627 \\
\hline & 25 & 13.010 .957 & $36.0 t 1.256$ \\
\hline & 50 & 8.511 .054 & 19.510 .548 \\
\hline \multirow{3}{*}{ PSLP } & 10 & 43.510 .692 & 66.510 .873 \\
\hline & 25 & $16.0 \mathrm{t} 1.274$ & 36.511 .115 \\
\hline & 50 & $8.0 \mathrm{t} 1.283$ & 17.010 .725 \\
\hline \multirow{3}{*}{ PSRM } & 10 & $58.5 \mathrm{t} 1.025$ & 77.010 .927 \\
\hline & 25 & 32.010 .628 & 46.510 .974 \\
\hline & 50 & 13.511 .174 & 25.011 .034 \\
\hline \multirow{3}{*}{ PSRP } & 10 & 39.510 .959 & 61.511 .361 \\
\hline & 25 & 12.511 .026 & $31.0 \mathrm{t} 1.148$ \\
\hline & 50 & 6.510 .869 & 17.511 .017 \\
\hline \multirow{2}{*}{ Piperazine citrate } & 10 & 7.0t 1.023 & 25.010 .681 \\
\hline & 20 & 4.510 .717 & $16.0 \pm 0.826$ \\
\hline
\end{tabular}

Table 4: Anthelmintic activity of the different fractions of P. stratiotes L. on the Indian earthworm.

\section{Conclusion}

In conclusion, it seems from this preliminary study that the leaf methanolic extracts of P. stratiotes $L$ have best inhibitor impact with IC50 values ninety six. $84,76.25$, and $46.11(\mu \mathrm{g} / \mathrm{mL})$ for DPPH radical scavenging, $\mathrm{NO}$ scavenging, and $\mathrm{Fe}^{3+}$ reducing technique, severally. The ethereal root extracts were shown the dose dependent increase in NO scavenging (IC50, $254.97 \mu \mathrm{g} / \mathrm{mL}$ ) and $\mathrm{Fe}^{3+}$ reducing activity (IC50, $47.97 \mu \mathrm{g} / \mathrm{mL}$ ) and for the methanolic root extract IC50 (Figure 1). Leaf extracts appeared pharmacologically effective as an antidiarrheal, and each leaf and root extracts could also be effective against 
worm by inducement palsy and death. additional investigation is required for the potential chemical constituents gift in it.

\section{Competing Interests}

Authors have declared that no competitive interests exist.

\section{References}

1. Kim HK, Choen BS, Kim YH, Kim SY, Kim HP (1999) Effects of naturally occurring flavonoids on nitric oxide production in the macrophage cell line RAW and their structure activity relationship. Biochem Pharmacol 5: 759-765.

2. Oyaizu M (1986) Studies on Products on Browning reaction Antioxidative activities of products of Browning reaction prepared from Glucosamine. Japanese J Nutr 44: 307-315.

3. Ajaiyeoba EO, Onocha PA, Olarenwaju OT (2001) In vitro anthelmintic properties of Buchholzia coriaceae and Gynandropsis gynandra extract. Pharm Biol 39: 217-220.

4. Martin RJ (1997) Mode of action of anthelmintic drugs. Vet J 154: 11-34.

5. Govindarajan R, Rastogi S, Vijayakumar M, Shirwaikar A, Rawat AKS, et al. (2003) Studies on the Antioxidant Activities of Desmodium gangeticum. Biol Pharm Bull 26: 1424-1427.

6. Yu L, Haley S, Perret J, Harris M, Wilson J, et al. (2002) Free radical scavenging properties of wheat extracts. J Agric Food Chem 50: 1619-1624.

7. Kumaran A, Karunakaran RJ (2007) In vitro antioxidant activities of methanol extracts of five Phyllanthus species from India. LWT-Food Science \& Technology 40: 344-352.

8. Meyer BN, Ferringni NR, Puam JE, Lacobsen LB, Nichols DE, et al. (1982) Brine shrimp: a convenient general bioassay for active constituents. Planta Med 45: 31-34.

9. Shoba FG, Thomas M (2001) Study of antidiarrhoeal activity of four medicinal plants in castor oil induced diarrhoea. J Ethnopharmacol 76: 73-76.

10. Ghani A (1998) Medicinal plants of Bangladesh: chemical constituents and uses. Cab Direct: 467.
11. Megha Jha, Ganesh N, Versha Sharma (2010) In vitro Evaluation of Free Radical Scavenging Activity of Pistia stratiotes. International Journal of Chem Tech Research 2: 180-184.

12. Joseph S, Sabulal B, George V, Smina TP, Janardhanan KK (2009) Antioxidative and Anti-inflammatory activities of the chloroform extract of Ganoderma lucidum found in south India. Sci Pharm 77: 111-121.

13. Boone CW, Kelloff GJ, Malone WE (1990) Identification of candidate cancer chemopreventive agents and their evaluation in animal models and human trials: A Review. Cancer Res 5: 2-9.

14. Longanga OA, Vercruysse A, Forriers A (2000) Contribution to the ethnobotanical, phytochemical and pharmacological studies of traditionally used medicinal plants in the treatment of dysentery and diarrhea in Lomela area, Democratic REPUBLIC of Congo (DRC). J Ethnopharmacol 71: 411-423.

15. Crozier A, Burns J, Aziz AA, Stewart AJ, Jenkins GI, et al. (2000) Antioxidant flavonoids from fruits, vegetables and beverages, measurements and bioavailability. Biol Res 33: 79-88.

16. Jagetia SC, Rosk, Balgia MS, Babu K (2004) Evaluation of nitric oxide scavenging activity of certain herbal formulations in vitro. Phyto Res 1: 561-565.

17. Vinson JA, Hao Y, Zubic SK (1998) Food antioxidant quantity and quality in foods: Vegetables. J Agric Food Chem 4: 3630-3634.

18. Khare CP (2007) Indian medicinal plants: An Illustrated Dictionary. Springer- Verlag Berlin Heidelberg, Germany.

19. Mora A, Paya M, Rios JL, Alcaraz MJ (1990) Structure activity relationships of polymethoxy flavones and other flavonoids as inhibitors of non-enzymic lipid peroxiation. Biochem Pharmacol 40: 793-797.

20. Mongelli E, Pomilio AB, Sanchez JB, Guerra FM, Massanet GM (2002) ent-Kaur-16-en-19-oic acid, a KB cells cytotoxic diterpenoid from Elaeoselinum foetidum. Phytother Res 16: 387-388.

21. Ayyad S (2002) A new cytotoxic stigmastane steroid from Pistia stratiotes. Pharmazie 57: 212-214.

22. Kirtikar KK, Basu BD (2001) The Indian medicinal Plants. Dehradun: Oriental Enterprises.

23. Duh PD, Tu YY, Yen GC (1999) Antioxidant activity of the aqueous extract of harn jyur (Chrysanthemum morifolium Ramat). LWT-Food Science \& Technology 32: 269-277. 